\title{
Nitric oxide emissions from forest soils
}

\author{
Saskia M. van Dijk ${ }^{1}$ and Jan H. Duyzer \\ TNO Institute of Environmental Sciences, Apeldoorn, Netherlands
}

\begin{abstract}
Nitric oxide (NO) fluxes to the atmosphere were determined from different soil types in coniferous forest and deciduous forest in the Netherlands. Dynamic chambers were used to determine the emission every week throughout a year. Forest type and soil texture are important parameters leading to large differences in fluxes between sites. High fluxes of up to $178 \mathrm{ng} \mathrm{m}^{-2} \mathrm{~s}^{-1}$ were observed in summer in a Douglas fir forest on a sandy soil. In a nearby beech forest, on the same soil, fluxes of up to $63 \mathrm{ng} \mathrm{m}^{-2} \mathrm{~s}^{-1}$ were observed. Emissions from clayey soils in a beech forest were much lower, ranging from 0 to $14 \mathrm{ng}$ $\mathrm{m}^{-2} \mathrm{~s}^{-1}$. Besides the important effect of the forest community type and the soil texture on the NO flux, a strong positive correlation with soil temperature was observed (accounting for up to $70 \%$ of the variance). Soil moisture could explain up to $60 \%$ of the variance of the NO flux. It seems that an optimum range of intermediate moisture content exists, ranging from 30 to $45 \%$ dry weight or from 55 to $85 \%$ water-filled pore space, approximately, where high temperatures lead to high emissions.
\end{abstract}

\section{Introduction}

Nitrogen oxides, together with hydrocarbons, play an important role in atmospheric ozone formation [Crutzen, 1983]. Furthermore, the oxidation of nitrogen dioxide to nitric acid is a major contributor to acid precipitation [Logan, 1983]. Policies to reduce levels of tropospheric ozone are often based on computer simulation models that rely on estimates of emissions from all relevant sources of hydrocarbons and nitrogen oxides. Especially on a global scale, the contribution of emissions of nitric oxide (NO) from natural sources to the NOy (NO plus other nitrogen oxides) budget is very significant [Davidson, 1991]. Few data are available on the emission rates of these trace gases from soils in temperate forests.

Earlier studies indicated that NO emitted from the soil is mainly produced by biological nitrification, the oxidation of organic nitrogen and/or ammonium $\left(\mathrm{NH}_{4}^{+}\right)$to nitrate $\left(\mathrm{NO}_{3}{ }^{-}\right)$ [Lipschultz et al., 1981], and denitrification, the reduction of $\mathrm{NO}_{3}^{-}$to $\mathrm{NO}$, nitrous oxide $\left(\mathrm{N}_{2} \mathrm{O}\right)$ and nitrogen [McKenny et al., 1982]. The NO flux from soil has been found to be strongly positively linked to temperature [Slemr and Seiler, 1984; Skiba et al., 1992]. A very small temperature response of NO emissions to temperature has been observed from extremely dry soils [Cardenas et al., 1993; Ludwig, 1994], indicating that soil moisture has an important control on the NO flux. Also, a strong link between rainfall amount and NO flux has been observed

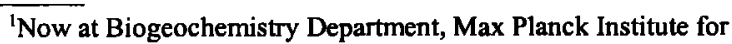
Chemistry, Mainz, Germany.

Copyright 1999 by the American Geophysical Union.

Paper number 1999JD900195.

0148-0227/99/1999JD900195\$09.00
[Skiba et al., 1992]. Other controlling variables are availability of $\mathrm{NO}_{3}^{-}$and $\mathrm{NH}_{4}{ }^{+}$[Galbally, 1989], soil acidity [Van Cleemput and Samater, 1996], and organic substrate [Slemr and Seiler, 1984]. Meixner [1994] gives a comprehensive review of the NO flux from soil and the main regulating parameters.

The Netherlands Organization for Applied Scientific Research (TNO) coordinated a European project (FOREXNOX) in which measurements of exchange rates of nitrogen oxides were carried out in various forests across Europe. The aims of this study were to establish NO fluxes at the soil-atmosphere interface in different forests as well as from different soils and to determine key factors regulating this flux. For this purpose, experiments were designed to cover a wide variety of conditions. These included measurements in areas with high (Netherlands) and low (Scotland) nitrogen inputs from the atmosphere, measurements in deciduous and coniferous forests, and measurements from different soil textures (sandy and clayey soils). In this paper, only the measurements carried out in the the Netherlands are presented. Measurements were carried out throughout the year, which made it possible to determine emissions under varying conditions with respect to soil temperature and wetness.

\section{Methods}

\subsection{Experimental Procedure}

Dynamic open chamber techniques as discussed by Mosier [1989] were used to measure the nitric oxide flux from soil. The stainless steel chambers $(1.50 \times 0.30 \times 0.25 \mathrm{~m})$ were sunk in the soil to $0.10 \mathrm{~m}$, giving a total volume of $0.0675 \mathrm{~m}^{3}$. Two fans were attached to the Plexiglas lid on top of each chamber to achieve adequate mixing of each of the air inside the chamber. The lid was placed on top of each of the chambers half an hour prior to the start of measurements. Using a ventilator, ambient air was pushed through a funnel over the enclosed soil within each 
chamber. The flow rate ranged from 0.008 to $0.010 \mathrm{~m}^{3} \mathrm{~s}^{-1}$ and was not found to be correlated to the NO flux. This suggests that small pressure differentials, induced by pushing the air over the soil, were not found to influence the NO emissions from soil. NO concentrations at the inlet and outlet of the chamber were determined using a Thermo Environmental Instruments $42 \mathrm{~W}$ monitor based on the chemiluminescent reaction between NO and ozone. The detection limit of the instrument was $0.1 \mathrm{ppb}$. Primary calibration of the instruments was carried out at the laboratory using permeation tubes for $\mathrm{NO}_{2}$ and standard gas mixtures for NO as primary standards $\quad(50.03 \mathrm{ppm}$ certified by the Dutch NMi). A mobile calibration unit was used in the field prior to each measurement campaign. The sampling procedure and data logging were controlled using a Campbell $21 \mathrm{X}$. Each measurement sequence took 1 hour, after which the Plexiglas lid was opened and measurements were made from the next chamber. In addition several physical and chemical aspects of the soil were monitored. Soil temperature, at a depth of $0.05 \mathrm{~m}$, was recorded simultaneously with the chamber experiments. The gravimetric water content of the soil was determined for each experimental site.

From July 1996, to August 1997 NO fluxes were determined on one day every week at Speuld in the central part of the Netherlands. In addition, NO fluxes were measured at Hollandse Hout during two field campaigns in summer 1997.

Table 1 presents various physical and chemical soil characteristics observed at Speuld and Hollandse Hout. Atmospheric deposition levels are high for both study areas, estimated to average $40 \mathrm{~kg} \mathrm{~N} \mathrm{ha}^{-1} \mathrm{yr}^{-1}$ and $30 \mathrm{~kg} \mathrm{~S} \mathrm{ha}^{-1} \mathrm{yr}^{-1}$ [Heij and Schneider, 1991].

The study area at Speuld is a 35-year-old forest stand which has several different plantations all on identical coarse-textured acidic soil (Table 1). In total, three permanently installed chambers were operational at Speuld, providing NO fluxes from three different experimental plots. NO emissions were determined in a Douglas fir (Pseudotsuga menziesii) plantation and a beech (Fagus) plantation. Since these two forest types were stocked on the same sandy soil, results could be used to study the impact of. tree species on the NO fluxes. Additionally, a third experimental site, situated within the Douglas fir plantation, was supplied on a weekly basis with $8 \mathrm{~mL}$ of an ammonium, nitrate, and sulfate solution, the components having concentrations of $0.042,0.010$, and $0.016 \mathrm{~mol} \mathrm{~kg}^{-1}$, respectively. By this procedure this site would receive an amount of nitrogen and sulfate equivalent to twice the normal annual deposition.

In addition to the continuous flux measurements at the study area at Speuld, two other dynamic chambers were installed at Hollandse Hout in March 1997. NO flux measurements were determined from two identical sites at Hollandse Hout during two field campaigns of several days in summer 1997. The study area at Hollandse Hout is a beech (Fagus) plantation in a 25-year-old forest which has several different forest communities. The soil has a very fine soil texture, consisting mainly of heavy clay (see table 1). Comparison of the NO fluxes from the beech plantation at Speuld (sandy soil) and the beech plantation at Hollandse Hout (clayey soil) were used to study the impact of soil texture on the NO flux.

\subsection{Calculation}

The NO flux was calculated from the difference in NO mixing ratios $(\mathrm{ppb}$ ) between inlet and outlet of the dynamic chamber and was corrected for bias due to chemical reactions between NO, $\mathrm{NO}_{2}$, and $\mathrm{O}_{3}$ (see below). The fluxes were calculated from:

$$
F_{\text {NO }}=\left\{\frac{Q}{A}\left(c_{\text {out }}-c_{\text {in }}\right)+F_{\text {cor }}\right\} \frac{M_{\mathrm{N}}}{V_{\mathrm{m}}}
$$

where $F_{\mathrm{NO}}$ (ng N m $\mathrm{m}^{-1}$ ) is the NO flux, $Q\left(\mathrm{~m}^{3} \mathrm{~s}^{-1}\right)$ is the flow rate through the chamber, $A\left(\mathrm{~m}^{2}\right)$ is the area enclosed by the frame, $c_{\text {in }}$ and $c_{\text {out }}$ are the NO concentrations at the inlet and outlet of the chamber respectively, and $V_{\mathrm{m}}\left(\mathrm{m}^{3} \mathrm{~mol}^{-1}\right)$ and $M_{\mathrm{N}}\left(\mathrm{kg} \mathrm{mol}^{-1}\right)$ are the molar volume and molar weight of nitrogen, respectively. $F_{\text {cor }}$ is a factor used to correct for the amount of NO consumed in the reaction with $\mathrm{O}_{3}$ (to form $\mathrm{NO}_{2}$ ) taking place in the enclosure and can be found by estimating the average reaction rate in the enclosure during monitoring. Air was alternately sampled and analyzed at the chamber inlet and chamber outlet, switching every $3 \mathrm{~min}$. Preliminary analysis of the data showed that a sudden unambiguously high or low ambient NO mixing ratio could result in errors in the calculated flux. Therefore the NO flux was numerically filtered to prevent bias from strong variations of the ambient NO mixing ratios. Averaging two successive NO mixing ratios of the ambient air effectively removed sudden leaps and proved to be a good method to reduce the variance in the calculated NO flux. Only a few flux measurements with large fluctuations of the NO mixing ratios at the inlet were rejected. In total, 4000 successful 6-min NO flux measurements resulted in 300 hourly averaged NO emission rates. The data set was tested for normal distribution (histograms), and parametric statistical tests ( $t$ tests) were used to determine significant differences between experimental sites.

\section{Results and Discussion}

Figure 1 presents the hourly averaged NO emissions observed at the different experimental sites at Speuld and Hollandse Hout.

Table 1. Summary of the Different Experimental Sites at Speuld $\left(52^{\circ} 13^{\prime} \mathrm{N}, 5^{\circ} 39^{\prime} \mathrm{E}\right)$ and Hollandse Hout $\left(52^{\circ} 26^{\prime} \mathrm{N}, 5^{\circ} 28^{\prime} \mathrm{E}\right)$

\begin{tabular}{|c|c|c|c|c|}
\hline & \multicolumn{3}{|c|}{ Speuld } & \multirow[t]{2}{*}{ Hollandse Hout } \\
\hline & Site 1 & Site 2 & Site 3 & \\
\hline Forest community & Douglas fir & beech & Douglas fir & beech \\
\hline Soll texture & loamy sand & loamy sand & loamy sand & heavy clay \\
\hline Soil classıfication & podsol & podsol & podsol & luvisol, no distinct horizons \\
\hline Soil acidity $\left(\mathrm{pH} \mathrm{H}_{2} \mathrm{O}\right)$ & 3.7 & 3.7 & 3.7 & 6.8 \\
\hline Organic matter $(0-5 \mathrm{~cm}), \%$ & 15 & 15 & 15 & 5 \\
\hline Organıc matter $(>50 \mathrm{~cm}), \%$ & 1.5 & 1.5 & 1.5 & 5 \\
\hline $\mathrm{CaCO}_{3}, \%$ & $\mathbf{0}$ & 0 & 0 & 1 \\
\hline $\mathrm{NH}_{4}^{+} / \mathrm{NO}_{3}^{-}, \mathrm{mg} \mathrm{N} \mathrm{kg}^{-1}$ & $4.9 / 38$ & - & - & - \\
\hline Special & & & $\mathbf{N}$ added & \\
\hline
\end{tabular}




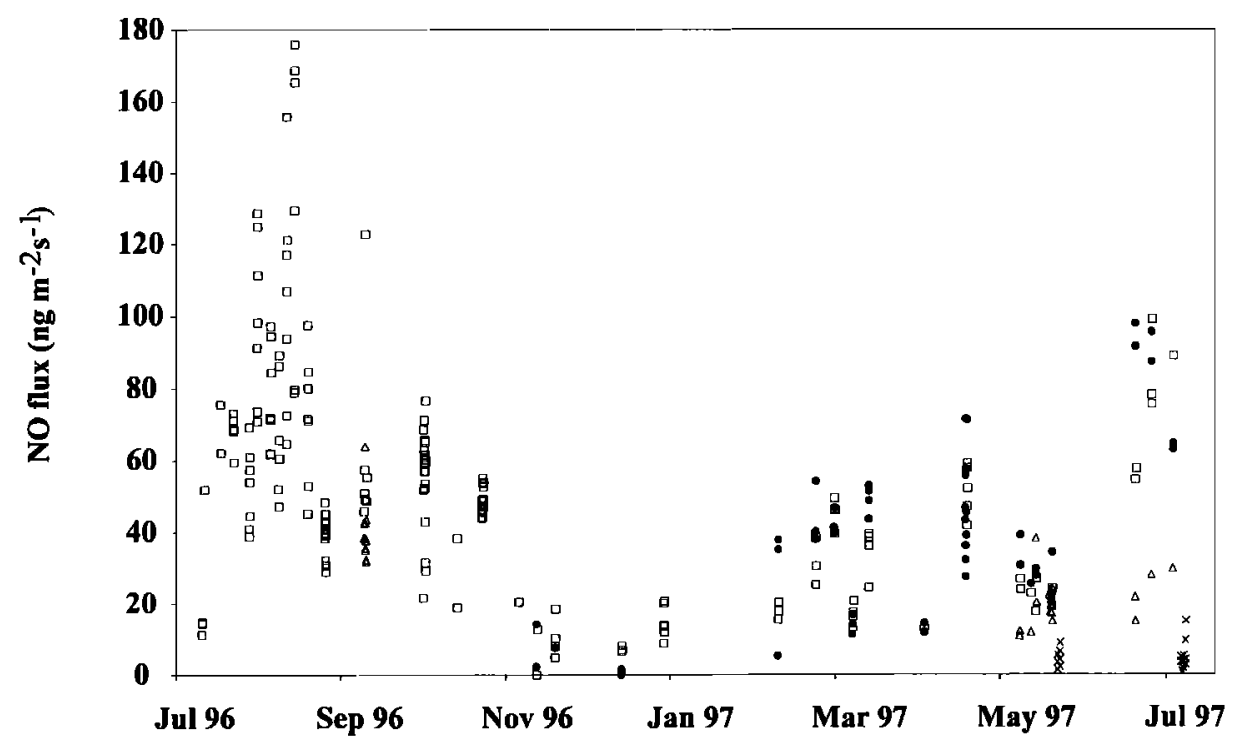

Figure 1. Hourly averaged NO fluxes observed at the different experimental sites at Speuld and Hollandse Hout. Maximum NO fluxes are found during summer and minımum NO fluxes are found during winter. Open squares, Douglas fir, sandy soil; Solid circles, Douglas fir, extra-N sandy soil; open triangles, beech, sandy soil; and crosses, beech, clayey soil.

The NO fluxes were found to differ considerably throughout the measuring period. The NO fluxes at Speuld were very high, varying from hardly detectable in winter to $180 \mathrm{ng} \mathrm{m}^{-2} \mathrm{~s}^{-1}$ in summer in a Douglas fir stand and up to $65 \mathrm{ng} \mathrm{m}^{-2} \mathrm{~s}^{-1}$ in the beech plantation. The average observed NO flux from the beech plantation at Hollandse Hout ranged from 0 to $15 \mathrm{ng} \mathrm{m}^{-2} \mathrm{~s}^{-1}$. Compared to results from other relevant studies, the NO fluxes observed at Speuld and Hollandse Hout were relatively high. In analogue studies in temperate coniferous forests in Germany and Denmark, NO fluxes were reported ranging from 0.14 to $6.7 \mathrm{ng}$ $\mathrm{m}^{-2} \mathrm{~s}^{-1}$, [Papen et al., 1993] and from 0.3 to $21 \mathrm{ng} \mathrm{m}^{-2} \mathrm{~s}^{-1}$ [Pilegaard et al., 1999] respectively. The relatively high NO fluxes observed during our study may well result from the high atmospheric N deposition. Butterbach-Bahl et al. [1997] also found relatively high NO emissions up to 28 and $40 \mathrm{ng} \mathrm{m}^{-2} \mathrm{~s}^{-1}$ from sandy soils in deciduous and coniferous forest, respectively. These values were thought to be linked to the high annual atmospheric deposition level of $35 \mathrm{~kg} \mathrm{~N} \mathrm{ha}^{-1} \mathrm{yr}^{-1}$, comparable to the $\mathrm{N}$ deposition at Speuld.

\subsection{Soil Temperature}

As a microbiological process, nitric oxide production is strongly linked to temperature, causing higher fluxes from soil in summer. At most, $70 \%$ of the variance in the determined NO flux was explained by soil temperature. Figure 2 shows the NO emission as a function of temperature for all sites. The activation energy was $85 \mathrm{~kJ} \mathrm{~mol}^{-1}$, as was calculated according to the

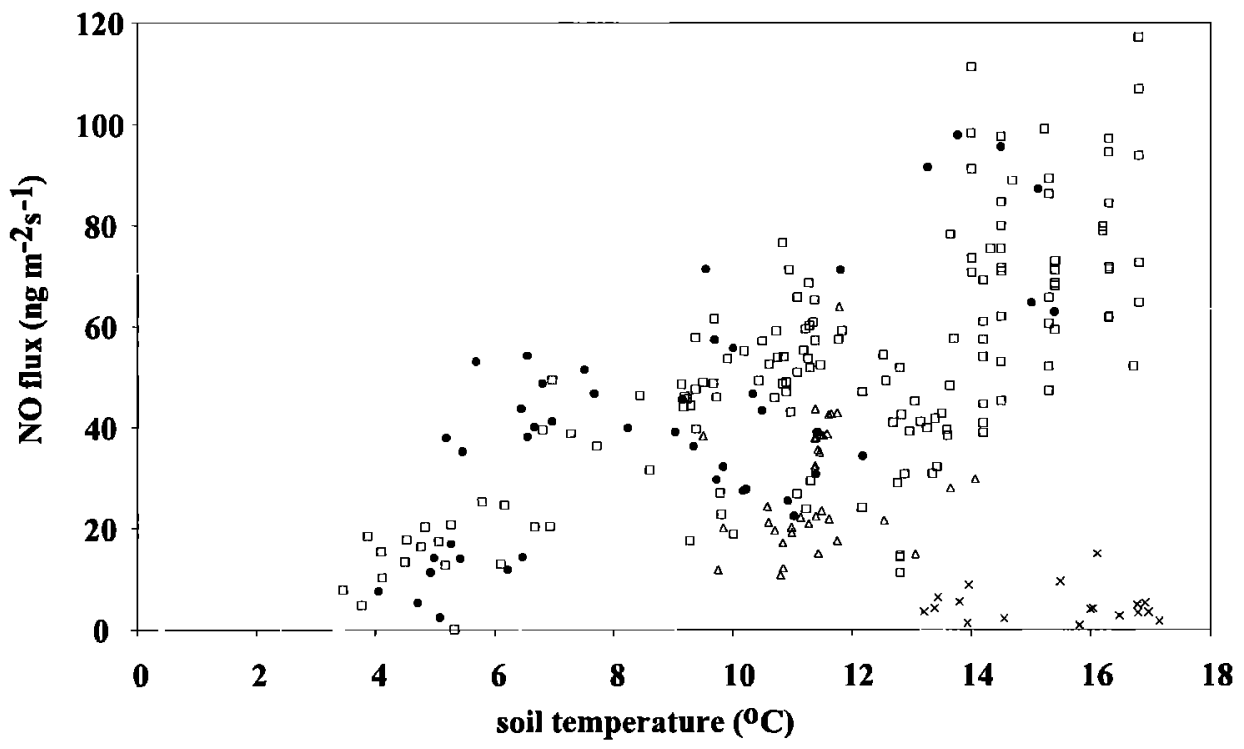

Figure 2. NO flux related to the temperature. The activation energy calculated according to the Arrhenius equation for data from the Douglas fir stand on sandy soil $1 \mathrm{~s} 85 \mathrm{~kJ} \mathrm{~mol}^{-1}$. Symbols are as in Figure 1. 
Arrhenius equation for data from the Douglas fir stand on sandy soil. At this experimental site, NO fluxes were determined during a complete year. The activation energy agrees well with values reported in other studies, ranging from 44 to $103 \mathrm{~kJ} \mathrm{~mol}^{-1}$ [Johansson and Granat, 1984; Skiba et al., 1992]. This indicates a twofold to threefold increase in the NO emission for each $10^{\circ}$ rise in temperature, as is commonly observed for microbiological processes [Focht and Verstraete, 1977; Galbally, 1989].

\subsection{Soil Moisture}

As is shown in Figure 3, a high NO emission rate was found particularly at a high soil temperature. Furthermore, it can be seen that maximum fluxes were observed at a specific range of soil moistures. If soil conditions are extremely dry, the microbial community suffers from water stress, limiting the biological production of NO. For instance, Cardenas et al. [1993] found hardly any effect on soil temperature at very dry soil conditions. Several studies have shown an explosion of NO emissions after wetting extremely dry soil, suggesting that the NO production in soil was water limited [Johansson and Sanhueza, 1988, Meixner et al., 1997; Scholes et al., 1997]. On the other hand, when soil pores are filled with water, the escape of NO molecules to the atmosphere is drastically retarded [Galbally, 1989]. An optimum soil water content offers sufficient moisture to enable microbial activity without hindering gas diffusion through the soil. Laboratory studies [Linn and Doran, 1984] indicated that production of trace gases $\left(\mathrm{CO}_{2}, \mathrm{~N}_{2} \mathrm{O}\right)$ in soil through aerobic microbial processes is at a maximum at a water-filled pore space of $60 \%$. (Water-filled pore space is the ratio of volumetric soil water content to total soil porosity [Hillel, 1980].) A water-filled pore space of $60 \%$ appeared to be the threshold between waterlimiting and aeration-limiting processes and was also suggested to be the optimum for NO emission from soil [Davidson, 1993]. During our experiment, maximum NO fluxes from sandy soil in coniferous forest were found at a soil water content varying between 30 and $45 \%$ (dry weight), at a water-filled pore space (WFPS) between 55 and $85 \%$ (Figure 3). NO production is possible not only through aerobic nitrification, but also through microbial processes under anaerobic conditions [Firestone and Davidson, 1989], and therefore the optimum soil water content for NO emission may be higher than $60 \%$ WFPS. The range of optimum water content is well in line with the field capacity of the sandy soils at Speuld, $85 \%$ and $40 \%$ WFPS in the soil layers from 0 to $0.06 \mathrm{~m}$ and from 0.08 to $0.14 \mathrm{~m}$ depth, respectively. Compared to our findings, results from a study in Venezuela showed maximum NO emissions from a sandy soil at a much lower water content, ranging from 10 to $20 \%$ (dry weight)

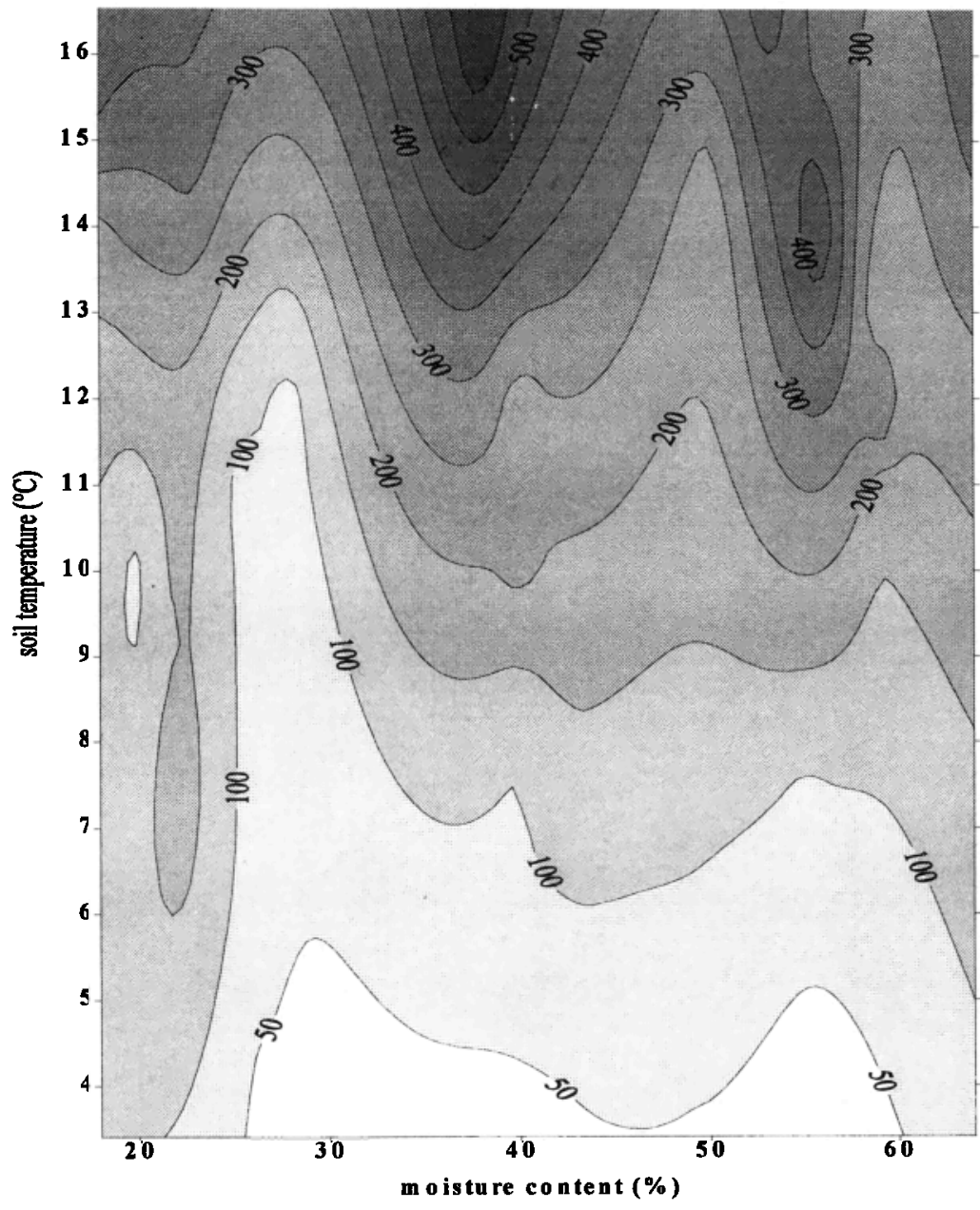

Figure 3. NO emissions (in $\mu \mathrm{g} / \mathrm{m}^{2} / \mathrm{hr}$ ) from the sandy soil site in the Douglas fir plantation related to both the temperature and the soil water content. High NO fluxes are restricted to a relatively high soil temperature, and maximum fluxes are observed at a certain intermediate range of soil water content (30-45\% dry weight). 
[Cardenas et al., 1993]. Possibly, in a given region the established microbial community has adapted to the prevailing environmental conditions. Therefore the optimum soil water content at which microbial production, together with gas diffusion, leads to maximum NO emission depends on the water regime of the study area. This implies that the optimum soil water content for maximum NO emission under relatively wet soil conditions (the Netherlands) would be higher than for dryer conditions (Venezuela), explaining the relatively higher optimum soil moisture found during this study.

\subsection{Atmospheric Nitrogen Input}

Figure 1 shows NO fluxes from two experimental sites in the Douglas fir forest at Speuld that have two different annual atmospheric $\mathrm{N}$ deposition levels. One of these received increased amounts of nitrogen. There is widespread evidence that the availability of organic and inorganic nitrogen in soils has a strong impact on NO emission rates [Slemr and Seiler, 1984]. For instance, the average NO flux from soils in a Sitka spruce forest in Scotland changed from 0.53 to $4.6 \mathrm{ng} \mathrm{m}^{-2} \mathrm{~s}^{-1}$ upon addition of nitrogen containing acid mist [Skiba et al., 1994]. However, the experimental site in the Douglas fir forest at Speuld that received an additional amount of nitrogen in addition to the annual atmospheric deposition level was not found to have significantly higher NO emissions. It is thought that the high annual deposition levels of $\mathrm{N}$ and $\mathrm{S}$ from the atmosphere observed by throughfall measurements carried out at Speuld (40 and $30 \mathrm{~kg} \mathrm{ha}$ ${ }^{1} \mathrm{yr}^{-1}$, respectively [Heij and Schneider, 1991]) have saturated the soil with nutrients. Addition of extra $\mathrm{N}$ would therefore not result in an increase in the NO flux from soil. This finding is in line with experiments carried out by Koopmans [1996], who showed on the basis of nitrogen leaching experiments that soils in the Douglas fir stand at Speuld are indeed nitrogen saturated.

\subsection{Soil Texture and Forest Type}

Figures 1 and 2 show that differences in forest type, or differences in soil parameters due to differences in forest type, influenced the NO flux from soil. Table 2 compares the average NO flux and standard deviations found for the different experimental sites. NO emission rates from sandy soll in Douglas fir forest were $30 \mathrm{ng} \mathrm{m}^{-2} \mathrm{~s}^{-1}$ higher than NO fluxes from sandy soil in beech forest. It remains uncertain which soil properties could have caused the higher flux from soil in coniferous forest, since the physical and chemical soil characteristics that were monitored at the two different experimental sites were all similar.
The soil $\mathrm{NH}_{4}^{+}$and $\mathrm{NO}_{3}^{-}$concentrations, found to be strongly positively linked to NO fluxes [Slemr and Seiler, 1984], were unfortunately not measured at the different experimental sites. Similar experiments in Germany, however, also demonstrated a smaller NO flux from soil in deciduous forest than from soil in coniferous forest. These differences were suggested to arise from differences in the soil microbial populations and processes and different turnover ratios of organic matter due to differences in litter quality [Butterbach-Bahl et al., 1997]. In a study concerning soil gas transport, Ball et al. [1997] found an impact of the structure of the leaf litter layer on the gas diffusion from soil. The laminar structure of a bed of deciduous leaves, compared with that formed by coniferous needles, induces a barrier to gaseous diffusion. This is in line with our findings, wherein a smaller NO flux was observed from soil within a deciduous plantation compared with that from soil within a coniferous forest.

Other possible causes of the difference could be the influence of the leaves on the penetration of direct sunlight, thereby increasing soil temperature in the coniferous forest compared with that in the deciduous forest, or the difference in throughfall amount and composition on soil processes. In a beech forest, most of the nutrients reach the soil through stem flow, making inorganic nitrogen compounds available for NO flux processes mainly directly around the stem [Thimonier, 1998]. Furthermore, measurements have shown that throughfall fluxes of nitrogen in the Douglas fir forest in Speuld are extremely large. This is partly thought to be linked to its large leaf area (double-sided leaf area index of $20 \mathrm{~m}^{2} \mathrm{~m}^{-2}$ ). Generally, throughfall fluxes within coniferous forests have been found to be much larger than within deciduous forests, such as a beech forest [Schaeffer and Reiners, 1990; Erisman and Draaijers, 1995]. The amount of nitrogen reaching the floor of the beech forest could therefore be a factor of 2 lower. This would explan the observed lower emission of nitrogen from the Speulder beech forest. The very large difference observed during our experiments in the emission rates from the two forest types indicates that the forest community is of major importance to the NO flux from soil.

Table 2 shows the average NO fluxes from two different soil textures. The NO emission rates from sandy soil were higher than the NO emission rates from clayey soil; on average, differences of $\sim 20 \mathrm{ng} \mathrm{m}^{-2} \mathrm{~s}^{-1}$ were observed. The total pore volume of a fine textured soil (clay) is somewhat larger, but the pores themselves are smaller than those of the coarse textured sandy soils [Hillel, 1980]. It is suggested that under similar field conditions, molecular diffusion was slower through the smaller pores in the clayey soil and that the microbiologically produced NO gases

Table 2. Comparison of the Hourly Averaged NO Emissions (Average and Standard Deviation) for the Different Experimental Sites at Speuld and Hollandse Hout

\begin{tabular}{llcccc}
\hline \multicolumn{1}{c}{ Location } & Measuring Period & $\begin{array}{c}\text { Average Flux, } \\
\mathrm{ng} \mathrm{m}^{-2} \mathrm{~s}^{-1}\end{array}$ & $\begin{array}{c}\text { Standard } \\
\text { Deviation }\end{array}$ & $n^{\mathbf{a}}$ & Significant Difference \\
\hline Douglas & Nov. 1996 to Aug. 1997 & 32.0 & 21 & 46 & no \\
Douglas N added & Nov. 1996 to Aug. 1997 & 39.0 & 16 & 46 & \\
Douglas sandy soil & May 1997 to July 1997 & 49.7 & 29.7 & 20 & \\
Beech sandy soil & May 1997 to July 1997 & 20.6 & 6.1 & 20 & yes \\
Beech sandy soil & May 1997 to July 1997 & 21.7 & 6.4 & 21 & \\
Beech clayey soil & June 1997 to July 1997 & 3.2 & 4.8 & 21 & yes $^{\mathrm{b}}$ \\
\hline
\end{tabular}

a The number of observations is denoted by $n$.

${ }^{b}$ NO fluxes are significantly different $(p<0.01)$ by paired $t$ tests. 
were consumed in various reactions [Van Cleemput and Samater, 1996]. Butterbach-Bahl et al. [1997] and Papen et al. [1993] reported a reduction in the NO flux from a spruce forest floor when liming the soil (deacidification). This is in line with our findings of smaller NO fluxes from the less acidic clayey soils at Hollandse Hout as compared with the high fluxes observed from the acidic sandy soils at Speuld. Under the acidic conditions ( $\mathrm{pH}$ $<5.5$ ) and high levels of organic matter at Speuld, nitrite $\left(\mathrm{NO}_{2}{ }^{*}\right)$ can spontaneously decompose to form $\mathrm{NO}$ and $\mathrm{NO}_{2}$ [Nelson, 1982]. This chemical denitrification has been shown to contribute considerably to the NO flux [Van Cleemput and Samater, 1996]. Whether differences in soil texture alone or additional soil characteristics, such as soil $\mathrm{pH}$, are responsible for the larger NO flux from sandy soil remains unresolved.

\section{Concluding Remarks}

From our study it can be concluded that the environmental factors controlling emissions from NO to soil are soil temperature and water content. Our studies showed how the NO flux from soil is positively correlated to soil temperature, a rise of $10^{\circ}$ in the temperature, doubling the microbial production rate of the trace gas. Maximum emission rates from soil were observed at an intermediate range of soil moisture content, where conditions stimulating both microbial production and molecular diffusion are optimal. Our results show maximum NO emissions from soll at a soil water content ranging from 30 to $45 \%$ dry weight or 55 to $85 \%$ WFPS.

Across the landscape, differences in soil texture and forest community type are probably the most important parameters in determining NO fluxes to the atmosphere. Differences between the NO flux from sandy and from clayey soils can be very large. The forest type most likely introduces differences in the microbial community and in the leaf litter covering the forest floor and hence strongly influences both NO production and gas diffusion from soil. Also, differences in nitrogen input by stem flow and throughfall of different forest species determine the soil nutrient content availability. The emissions observed in our studies in the Netherlands were very large. It has been suggested that these large fluxes are linked to the large input of nitrogen from the atmosphere in these regions. An artificially increased nitrogen input from the atmosphere, however, did not increase the NO emission. This phenomenon is probably linked to the soil already being saturated with nitrogen at this site.

On the basis of our study and the literature information we conclude that when estimating the NO flux from natural environments on a regional scale, it is important to take into account differences in forest type, soil texture, and nitrogen input from the atmosphere. These quantities are likely to differ on a regional scale and are found to have a major influence on the magnitude of the NO flux from soil.

Acknowledgments. The financial support for our study provided by the Commission of the European Communities (DGXII) is kindly acknowledged. The authors would also like to thank the Faculty of Earth Sciences in Utrecht for permission to use the laboratory for chemical analysis of the soil samples. Discussions with Simon Vriend (University of Utrecht), Geert Draayers (TNO), and Albert Tietema (University of Amsterdam) were greatly appreciated. We thank the Boswachterij Flevoland and RIVM for their permission to carry out fieldwork on their properties. The help of Hilbrand Weststrate in the experimental work is kindly acknowledged. The anonymous reviewers are thanked for thorough reviews and useful suggestions.

\section{References}

Ball, B. C., K. E. Dobbie, J. P. Parker and K. A. Smith, The influence of gas transport and porosity on methane, J. Geophys. Res., I02(D19), 23,301-23,308, 1997.

Butterbach-Bahl, K., R. Gasche, L. Breuer and H. Papen, Fluxes of NO and $\mathrm{N}_{2} \mathrm{O}$ from temperate forest soils: Impact of forest type, $\mathrm{N}$ deposition and of liming on the $\mathrm{NO}$ and $\mathrm{N}_{2} \mathrm{O}$ emissions, Nutr. Cycling Agroecosyst., 48, 79-90, 1997.

Cardenas, L., A. Rondon, C. Johansson and E. Sanhueza, Effects of soil moisture, temperature, and inorganic nitrogen on nitric oxide emissions from acidic tropical savannah soils, J. Geophys. Res., 98(D8), 14,783-14,790, 1993.

Crutzen, P. J., Atmospheric interactions-homogeneous gas phase reactions of $\mathrm{C}, \mathrm{N}$, and $\mathrm{S}$ compounds, in The Major Biochemical Cycles and Their Interactions, edited by B. Bolin and R. B. Cook, SCOPE, 21, 67-114, 1983.

Davidson, E. A., Fluxes of nitrous oxide and nitric oxide from terrestrial ecosystems in Microbial Production and Consumption of Greenhouse Gases: Methane, Nitrogen Oxides and Halomethanes, edited by J. E. Rogers and W. B. Whitman, pp. 219-236, Am. Soc. for Microbiol., Washington, D. C., 1991.

Davidson, E. A., Soil water content and the ratio of nitrous oxide to nitric oxide emitted from soll, in Biogeochemistry of Global Change. Radiatively Active Trace Gases, edited by R. S. Oremland, pp. 369386, Chapman and Hall, New York, 1993.

Erisman, J. W., and G. P. J. Draaijers, Atmospheric deposition in relation to acidification and eutrophication, Stud. Environ. Sci., 63, 253-357, 1995.

Firestone, M. K., and E. A. Davidson, Microbiological bases of NO and $\mathrm{N}_{2} \mathrm{O}$ production and consumption in soil, in Exchange of Trace Gases Between Terrestrial Ecosystems and the Atmosphere, edited by M. 0 . Andreae and D. S. Schimel, pp. 7-21, John Wiley, New York, 1989.

Focht, D. D., and W. Verstraete, Biochemical ecology of nitrification and denitrification, Adv. Microb. Ecol., 1, 135-214, 1977.

Galbally, I. E., Factors controlling $\mathrm{NO}_{\mathrm{x}}$ emissions from soils, in Exchange of Trace Gases Between Terrestrial Ecosystems and the Atmosphere, edited by M. O. Andreae and D. S. Schimel, pp. 23-28, John Wiley, New York, 1989.

Heij, G. T., and T. Schneider, Acidification research in the Netherlands, in Final report of the Dutch Priority Programme of Acidification, pp. 60-275, Elsevier, New York, 1991.

Hillel, D., Introduction to Soil Physics, pp. 76-78, 137-142, Academic, San Diego, Calif., 1980.

Johansson, C., and E. Sanhueza, Emission of NO from tropical savanna soils during rainy season, $J$. Geophys. Res., 93(D11), pp. 14,19314,198, 1988.

Johansson, C., and L. Granat, Emission of nitric oxide from arable land, Tellus Ser. B, 36, 25-37, 1984.

Koopmans, C. J., The impact of reduced nitrogen deposition on nitrogen cycling in the Dutch forest ecosystems, Ph.D. thesis, Univ. of Amsterdam, Amsterdam, 1996.

Linn, D. M., and J. W. Doran, Effects of water-filled pore space on carbon dioxide and nitrous oxide production in tilled and nontilled soils, Soil Sci. Soc. Am. J., 48, 1267-1272, 1984.

Lipschultz, F., O. C. Zafiriou, S. C. Wofsy, M. B. McElroy, F. W. Valois, and S. W. Watson, Production of $\mathrm{NO}$ and $\mathrm{N}_{2} \mathrm{O}$ by soil nitrifying bacteria, Nature, 294, 641-643, 1981.

Logan, J. A., Nitrogen oxides in the troposphere: Global and regional budgets, J. Geophys. Res., 88(C15), 10,785-10,807, 1983.

Ludwig, J., Untersuchungen zum Austausch von Stickoxiden zwischen Biospäre und Atmosphäre, Ph.D. thesıs, Unıv. of Bayreuth, Bayreuth, Germany, 1994.

McKenny, D. J., K. F. Shuttleworth, and W. I. Findlay, Production and loss of nitric oxide from denitrification in anaerobic Brookston clay, Appl. Environ. Microbiol., 43, 541-543, 1982.

Meixner, F. X., Surface exchange of odd nitrogen oxides, Nova Acta Leopold., 70(288), 228-230, 1994

Meixner, F. X., T. Fickinger, L. Marufu, D. Serca, F. J. Nathaus, E. Makına, L. Mukurumbira, and M. O. Andreae, Prelimınary results on nitric oxide emission from a southern African savanna ecosystem, Nutr. Cycling Agroecosyst., 48, 123-138, 1997.

Mosier, A. R., Chamber and isotope techniques, in Exchange of Trace Gases Between Terrestrial Ecosystems and the Atmosphere, edited by M. O. Andreae and D. S. Schimel, pp. 175-187, John Wiley, New York, 1989. 
Nelson, D. W., Gaseous losses of nitrogen other than through denitrification, in Nitrogen in Agricultural Soils, edited by F. J. Stevenson, pp. 327-364, Am. Soc. of Agron., Madison, Wisc., 1982.

Papen, H., B. Hellmann, H. Papke and H. Rennenberg, Emissions of $\mathrm{N}$ oxides from acid irrigated and limed soils of a coniferous forest in Bavaria, in Biogeochemistry of Global Change: Radiatively Active Trace Gases, edited by R. S. Oremland, pp. 95-103, Chapman and Hall, New York, 1993.

Pilegaard, K., P. Hummelshøj, and P. O. Jensen, Nitric oxide emission from a Norway spruce forest floor, J. Geophys. Res., 104, 3433-3445, 1999.

Schaefer, D. A. and W. A. Reiners, Throughfall chemistry and canopy processing mechanısms, in Acid Precipitation, Sources, Deposition and Canopy Interactions, edited by S. E. Lindberg, A. L. Page and S. A. Norton, vol. 3, pp. 241-284, Springer-Verlag, New York, 1990.

Scholes, M. C., R. Martin, R. J. Scholes, D. Parsons, and E. Winstead, $\mathrm{NO}$ and $\mathrm{N}_{2} \mathrm{O}$ emissions from savanna soils following the first simulated rains of the season, Nutr. Cycling Agroecosyst., 48, 115 122, 1997.

Skiba, U., K. J. Hargreaves, D. Fowler, and K. A. Smith, Fluxes of nitric and nitrous oxides from agricultural soils in a cool temperate climate, Atmos. Environ. Part A, 26(14), 2477-2488, 1992.
Skiba, U., D. Fowler, and K. A. Smith, Emissions of $\mathrm{NO}$ and $\mathrm{N}_{2} \mathrm{O}$ from soils, Environ. Monit. Assess., 3I, 153-158, 1994.

Slemr, F., and W. Seiler, Field measurements of $\mathrm{NO}$ and $\mathrm{N}_{2} \mathrm{O}$ emissions from fertilized and unfertilized soils, J. Atmos. Chem., 2, 1-24, 1984.

Thimonier, A., Measurement of atmospheric deposition under forest canopies: Some recommendations for equipment and sampling design, Environ. Monit. Assess., 52, 353-387, 1998.

Van Cleemput, O., and A. H. Samater, Nitrite in soils: Accumulation and role in the formation of gaseous $\mathrm{N}$ compounds, Fertil. Res., 45, 81$89,1996$.

J.H. Duyzer, TNO Institute of Environmental Sciences, Laan van Westenenk 501, P.O. Box 342, 7300 AM Apeldoom, Netherlands. (Duyzer@mep.tno.nl)

S.M. van Dijk, Biogeochemistry Department, Max Plank Institute for Chemistry, P.O. Box 3060 Mainz, Germany. (svd@mpch-mainz.mpg.de)

(Received September 15, 1998; revised March 18, 1999; accepted March 22, 1999.) 